\title{
Donor Iymphocyte infusions in adolescents and young adults for control of advanced pediatric sarcoma
}

\author{
Sebastian J. Schober ${ }^{1}$, Irene von Luettichau ${ }^{1}$, Angela Wawer $^{1}$, Maximilian \\ Steinhauser $^{1}$, Christoph Salat ${ }^{2}$, Wolfgang Schwinger ${ }^{3}$, Marek Ussowicz ${ }^{4}$, Petar \\ Antunovic ${ }^{5}$, Luca Castagna ${ }^{6}$, Hans-Jochem Kolb ${ }^{1}$, Stefan E.G. Burdach ${ }^{1,7, *}$ and Uwe \\ Thiel $^{1, *}$ \\ ${ }^{1}$ Department of Pediatrics and Children's Cancer Research Center, TUM School of Medicine, Technical University of Munich, \\ Kinderklinik München Schwabing, 80804 Munich, Germany \\ ${ }^{2}$ Medical Center for Hematology and Oncology Munich MVZ, 80639 Munich, Germany \\ ${ }^{3}$ Department of Pediatrics, Medical University of Graz, A-8036 Graz, Austria \\ ${ }^{4}$ Department of Pediatric Oncology, Hematology and Bone Marrow Transplantation, Wroclaw Medical University, 50-368 \\ Wroclaw, Poland \\ ${ }^{5}$ Department of Hematology and Regional Tumor Registry, University Hospital Linköping, 58185 Linköping, Sweden \\ ${ }^{6}$ Department of Oncology and Hematology, IRCCS Humanitas Cancer Center, Humanitas University, 20089, Milan, Italy \\ ${ }^{7}$ CCC München-Comprehensive Cancer Center, DKTK German Cancer Consortium Munich, 80336 Munich, Germany \\ *These authors share senior authorship \\ Correspondence to: Sebastian J. Schober, email: sebastianjohannes.schober@tum.de \\ Keywords: donor lymphocyte infusion; allogeneic stem cell transplantation; Ewing sarcoma; rhabdomyosarcoma; alloimmunity \\ and transplantation \\ Received: January 19, $2018 \quad$ Accepted: April 06, $2018 \quad$ Published: April 27, 2018
}

Copyright: Schober et al. This is an open-access article distributed under the terms of the Creative Commons Attribution License 3.0 (CC BY 3.0), which permits unrestricted use, distribution, and reproduction in any medium, provided the original author and source are credited.

\section{ABSTRACT}

Background: Allogeneic stem cell transplantation (allo-SCT) and donor lymphocyte infusions (DLI) may induce a graft-versus-tumor effect in pediatric sarcoma patients. Here, we describe general feasibility, toxicity and efficacy of DLI after allo-SCT.

Results: 4 of 8 patients responded. ES\#4 had stable disease (SD) for 9 months after DLI and RMS\#4 partial response for 8 months with combined hyperthermia/ chemotherapy. In ES\#4, DLI led to SD for 6 months and reverted residual disease before allo-SCT into complete remission. After DLI, ES\#4 and RMS\#4 developed acute GvHD ( ${ }^{\circ}$ III- ${ }^{\circ}$ IV), ES\# 4 also developed chronic GvHD. 5 patients including ES\# 4 lived longer than expected. Median survival after allo-SCT was 2.3 years, post-relapse survival (PRS) was 13 months. Off note, HLA-mismatched DLI were associated with a trend towards increased survival after allo-SCT and increased PRS compared to HLA-matched DLI ( 23 versus 3 months).

Materials and Methods: We studied eight adolescents and young adults (AYAs) with advanced Ewing sarcoma (ES\# 1-4) and rhabdomyosarcoma (RMS\# 1-4) who received DLI. Escalating doses ranged from $2.5 \times 10^{4}$ to $1 \times 10^{8} \mathrm{CD}^{+}$cells $/ \mathrm{kg}$ body weight. AYAs were evaluated for response to DLI, graft-versus-host disease (GvHD) and survival.

Conclusions: DLI after allo-SCT may control advanced pediatric sarcoma in AYAs with controllable toxicity. 


\section{INTRODUCTION}

Patients with advanced Ewing sarcoma (ES), defined as $\geq 2$ bone metastases, and/or bone marrow involvement or relapse $\leq 2$ years after diagnosis have poor prognoses [1]. Intensified therapy regimens including high-dose chemotherapy (HDC), involved field irradiation, autologous and allogeneic stem cell transplantation (autoand allo-SCT) [2] could improve survival in some of these patients, excluding patients with bone marrow (BM) infiltration who do not survive irrespective of therapy [3]. Advanced rhabdomyosarcoma (RMS) patients with metastatic disease at diagnosis or those with recurrent disease have 5-year-survival rates not exceeding 30\% [4].

Whereas the presence of a graft-versus-leukemia effect has been shown, a hypothesized graft-versustumor (GvT) effect after allo-SCT in solid pediatric tumors has not yet been proven [5-7]. In ES, an inflammatory environment may have tumorigenic and immunosuppressive effects [8]. Allogeneic stem cell transplantation (allo-SCT) may abrogate diseasemaintaining homeostasis and induce a favorable antitumor immunity [9]. However, it may also cause life-threatening GvHD abolishing any beneficial effect of this approach [10]. We believe that allo-SCT has the potential to render ES and RMS susceptible to cellular immunotherapy due to the recognition of foreign histocompatibility antigens and an adjuvant effect of inflammatory responses in alloimmune reactions. Indeed, the application of tumorredirected TCR-transgenic T cells in two ES patients with haploidentical transplants did not cause GvHD and led to a partial tumor regression in at least one patient [11]. However, due to the Human Leukocyte Antigen (HLA)restriction of TCR-transgenic T cells, this treatment is currently limited to HLA-A2 positive ES patients. For all other patients, non-specific DLI may constitute an option.

To our knowledge, the role of non-specific DLI after allo-SCT in ES and RMS patients has not yet been studied systematically.

\section{RESULTS}

\section{Disease outcome after DLI}

4 out of 8 patients had a favorable clinical outcome after treatment modalities including DLI. Combination therapy of DLI and hyperthermia/chemotherapy were associated with SD for 9 months (ES\#2, Supplementary Figure 1) and in patient RMS\#4 with partial remission lasting 8 months (Figure 1A, 1B). Furthermore, DLI in patient ES\#4 reverted residual disease before allo-SCT into complete remission and led to a course of SD lasting 6 months under repetitive DLI. Patient RMS\#2 remained in $\mathrm{CR}$ for 97 months after his post-transplant treatment for relapsed disease including seven doses of DLI following surgical resection and salvage chemotherapy. In this analysis, responses to combination treatments including DLI were neither associated with the underlying disease nor a higher or lower frequency of certain matched or mismatched HLA-haplotypes (data not shown). Of note, 3 patients with responding clinical disease had received haploidentical grafts and DLI (ES\#2, ES\#4, RMS\#4).

\section{Graft-versus-host disease after DLI}

2 patients (ES\#4 and RMS\#4) developed acute ${ }^{\circ} \mathrm{II}-$ ${ }^{\circ}$ IV GvHD after DLI and patient ES\#4 suffered from extensive chronic GvHD for 108 days. Patient RMS\#3 developed limited chronic GvHD after allo-SCT but not after DLI. GvHD symptoms were controlled with steroids, mycophenolat mofetil, basiliximab/etanercept, repetitive extracorporal photopheresis (ECP) and thirdparty mesenchymal stem cells. Altogether high doses of donor lymphocytes were relatively well tolerated and did not lead to fatal complications (Tables 1 and 2).

\section{Median overall survival after allo-SCT and median post-relapse survival}

Altogether, 7 out of 8 patients died due to progressive disease. Median OS after allo-SCT of all patients was 27.5 months. Median OS after allo-SCT of ES patients was 36.5 months and 22 months for RMS patients. Median OS after allo-SCT for patients receiving haploidentical grafts was 40 months versus 10 months for patients receiving HLA-matched grafts. Median time to death after most recent relapse (PRS) of all patients was 13 months. Median time to death after most recent relapse for patients receiving haploidentical grafts was 23 months versus 3 months for patients receiving HLA-matched grafts.

\section{Individual outcomes}

ES\#1 was in complete remission (CR) after allo-SCT for 13 months until he suffered from a multifocal relapse. Relapsed disease was treated with irinotecan/temozolomide/ temsirolimus alternating with cyclophosphamide/topotecan chemotherapy, involved field irradiation and 6 repetitive DLI with up to $5 \times 10^{6} \mathrm{CD}^{+}$cells $/ \mathrm{kg}$ body weight. He showed no signs of GvHD after DLI. Tumor lesions did not respond to any treatment and progressed until DOD. ES\#2 was in CR after allo-SCT for 16 months until a distant pulmonary metastasis was confirmed. Relapsed disease was treated with 7 DLI with up to $1 \times 10^{7} \mathrm{CD}^{+}$cells $/ \mathrm{kg}$. Prior to each DLI, preparative hyperthermia with concurrent ifosfamide/ carboplatin/etoposide chemotherapy in reduced dosages (mini-ICE) was administered. He had stable pulmonary disease for 7 months after DLI without any signs of GvHD (Supplementary Figure 1). The patient suffered from tumor progression after 12 months ( 7 months after 1st DLI) and received molecular targeted therapies in combination with 
Table 1: Patient characteristics and individual outcomes

\begin{tabular}{|c|c|c|c|c|c|c|c|c|c|c|c|c|c|c|c|}
\hline 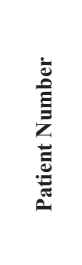 & نัّ & 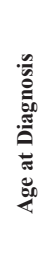 & 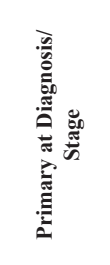 & 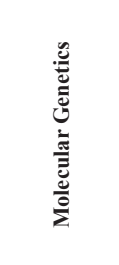 & 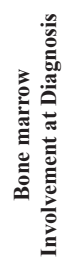 & 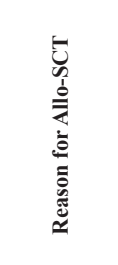 & 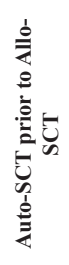 & 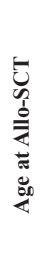 & 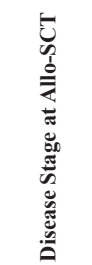 & 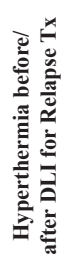 & 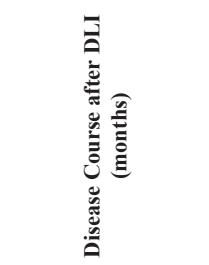 & 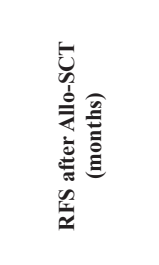 & 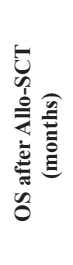 & 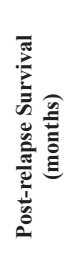 & 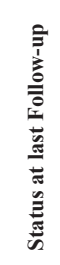 \\
\hline ES\#1 & $\mathrm{m}$ & 15 & multifocal & $\begin{array}{c}\text { EWS-FLI1 } \\
\text { (type 1) }\end{array}$ & Yes & $\begin{array}{c}\text { multifocal } \\
\text { disease }\end{array}$ & Yes & 16 & $\mathrm{CR}$ & No & PD & 13 (relapse) & 24 & 11 & DOD \\
\hline ES\#2 & $\mathrm{m}$ & 15 & multifocal & $\begin{array}{c}\text { EWS-FLI1 } \\
\text { (type 1) }\end{array}$ & Yes & $\begin{array}{c}\text { multifocal } \\
\text { disease }\end{array}$ & Yes & 16 & $\mathrm{CR}$ & Yes & $\mathrm{SD}(7 \mathrm{~m})$ & 16 (relapse) & 49 & 33 & DOD \\
\hline ES\#3 & $\mathrm{f}$ & 17 & multifocal & $\begin{array}{c}\text { EWS-FLI1 } \\
\text { (type 2) }\end{array}$ & Yes & $\begin{array}{c}\text { multifocal } \\
\text { disease }\end{array}$ & Yes & 18 & $\mathrm{PD}$ & No & PD & 0 (never in $\mathrm{CR}$ ) & 5 & N.A. & DOD \\
\hline ES\#4 & f & 17 & local & $\begin{array}{l}\text { EWS-FLI1 } \\
\text { (type 1) }\end{array}$ & No & $\begin{array}{l}\text { multifocal } \\
\text { relapse }\end{array}$ & Yes & 21 & $\begin{array}{c}\text { residual } \\
\text { disease }\end{array}$ & No & $\begin{array}{c}\text { CR }(9 \mathrm{~m}) \text { after } \\
4 \mathrm{DLI} \text {; SD }(6 \mathrm{~m}) \\
\text { under repetitive DLI }\end{array}$ & 19 (relapse) & 62 & 43 & DOD \\
\hline RMS\#1 & $\mathrm{f}$ & 15 & IV & UK & UK & $\begin{array}{l}\text { Relapse } \\
\text { after initial } \\
\text { treatment }\end{array}$ & No & 19 & $\mathrm{CR}$ & No & PD & 6 & 8 & 2 & DOD \\
\hline RMS\#2 & $\mathrm{m}$ & 14 & IV & embryonal & No & No CR & No & 14 & $\mathrm{CR}$ & No & $\mathrm{CR}$ & 28 & 97 & 69 & $\begin{array}{l}\text { Alive } \\
\text { in CR }\end{array}$ \\
\hline RMS\#3 & $\mathrm{f}$ & 25 & IV & alveolar & Yes & No $C R$ & Yes & 26 & $\mathrm{CR}$ & No & PD & 10 & 13 & 3 & DOD \\
\hline RMS\#4 & $\mathrm{f}$ & 14 & IV & alveolar & Yes & No $C R$ & Yes & 14 & $\mathrm{CR}$ & Yes & PR (8 m) & 18 & 31 & 13 & DOD \\
\hline
\end{tabular}

Abbreviations: allo-SCT = allogeneic stem cell transplantation; auto-SCT = autologous stem cell transplantation; $\mathrm{CR}=$ complete remission; DLI = donor lymphocyte infusion; DOD = death of disease; $\mathrm{ES}=$ Ewing sarcoma; GvHD = graft-versus-host disease: $\mathrm{OS}=$ overall survival; $\mathrm{PD}=$ progressive disease; $\mathrm{PR}=$ partial remission; $\mathrm{RFS}=$ relapse-free survival; $\mathrm{SD}=$ stable disease; $\mathrm{UK}=$ unknown.

salvage chemotherapy regimens (vorinostat/paclitaxel/ vincristine), which led to a course of SD for 5 months. Afterwards, the patient became refractory to other combinatory treatments (vorinostat/sorafenib/tretinoin and rapamycin/dasatinib/temozolomide) and died of pulmonary disease progression (DOD). ES\#3 had treatment-refractory PD and did not develop GvHD despite DLI (twice) with 1 $\times 10^{6} \mathrm{CD}^{+}$cells $/ \mathrm{kg}$ until she died of disease progression (DOD; Supplementary Figure 2). ES\#4 had residual disease at the time of allo-SCT, which was reverted into CR after 4 DLI with up to $3 \times 10^{5} \mathrm{CD}^{+}$cells $/ \mathrm{kg}$. She developed extensive chronic GvHD for 108 days and stayed in CR for 19 months. Distant, localized relapse was treated with weekly DLI (60 times) with up to $3 \times 10^{5} \mathrm{CD}^{+} / \mathrm{kg}$ in combination with local irradiation. This therapy regimen led to a course of SD for 6 months without any signs of GvHD. PD was again treated with 5 DLI containing up to $2 \times 10^{6} \mathrm{CD}^{+}$cells $/ \mathrm{kg}$ in combination with weekly bevacizumab and local irradiation. Treatment was discontinued because of acute GvHD ${ }^{\circ} \mathrm{III}-$ ${ }^{\circ}$ IV (gut, liver). Symptoms were controlled with steroids, mycophenolat mofetil, basiliximab and repetitive ECP. After GvHD control, disease progressed until DOD.

RMS\#1 did not show any signs of GvHD despite 2 DLI with $1 \times 10^{7} \mathrm{CD}^{+} / \mathrm{kg}$. She relapsed 6 months after alloSCT and died 2 months later due to disease progression. RMS\#2 was in CR for 28 months after allo-SCT before he relapsed. He was then treated with surgery and chemotherapy according to the CWS 96 relapse protocol. Consecutively, 7 escalating doses of donor lymphocytes with up to $1 \times 10^{8} \mathrm{CD}^{+} / \mathrm{kg}$ in combination with interleukin-2 (25 million units in total) in-between the 5th and 6th DLI were administered. At the time of data assessment, he was alive in CR for 97 months without any signs of GvHD. RMS\#3 developed acute GvHD ( $\left.{ }^{\circ} \mathrm{III}\right)$ and limited chronic GvHD after allo-SCT. Despite break of immune tolerance, she relapsed and suffered from refractory PD after 10 months, which was treated with irradiation and one infusion of $1 \times$ $10^{8} \mathrm{CD}^{+} / \mathrm{kg}$ donor lymphocytes. Chronic GvHD was absent before DLI. The patient then became treatment-refractory and died of disease progression (DOD). RMS\#4 stayed in CR for 18 months after allo-SCT until she relapsed and received one dose of $1 \times 10^{6} \mathrm{CD}^{+} / \mathrm{kg}$ donor lymphocytes upfront, as well as hyperthermia/mini-ICE. Thereafter, she developed ${ }^{\circ} \mathrm{II}-{ }^{\circ} \mathrm{III}$ acute skin GvHD, which was controlled with methylprednisolone. The hyperthermia/chemotherapy regimen was then continued and the patient experienced good PR of pancreatic as well as multiple lymph node metastases (Figure 1). PR lasted for 8 months until disease progressed leading to DOD. Individual survival data for all patients is shown in Figure 2.

\section{DISCUSSION}

Patients with advanced ES and RMS may become eligible for allo-SCT to induce a hypothesized GvT effect. This approach, however, may result in lifethreatening toxicities and GvHD. In the past, reduced intensity conditioning (RIC) was implemented to reduce HDC-associated toxicity and to facilitate a GvT effect in those patients. However, reduced toxicity was bought 
with higher relapse rates leading to equal OS compared to HDC-based regimen and the role of allo-SCT to induce a GvT effect remained unclear [1]. Most pediatric tumors are considered poorly immunogenic compared to e.g. melanoma or lung cancer, correlating with low response rates to immune-checkpoint inhibitors $[12,13]$. Further immune-evasive factors, such as low or varying HLA class I expression in-between patients and tumor sites, immune-modulatory pro-neoplastic effects of the tumor-microenvironment (TME) or high frequencies of regulatory $\mathrm{T}$ cells $\left(\mathrm{T}_{\text {regs }}\right)$ have been described [14-17]. Thus, strategies to render those tumors susceptible to immunotherapeutic approaches are needed. We hypothesize that allo-SCT does not constitute an endpoint but a starting point of immunotherapy in a subgroup of patients yet to be defined. Several reports such as the use of adjuvant tumor lysate-pulsed dendritic cell vaccination in patients after standard antineoplastic treatment [18] as well as the use of natural killer (NK) cells raise hope that ES may become targetable with immunotherapy [19, 20]. In the present analysis, 4 out of 8 patients responded to treatments including DLI. Clinical responses in patient ES\#2 and RMS\#4 were achieved with additional hyperthermia and mini-ICE. Apart from conversion to CR (after allo-SCT) and SD with weekly DLI in patient ES\#4, DLI-associated tumor responses were observed in combination approaches (e.g. hyperthermia, mini-ICE). 5 out of 8 patients lived longer than expected compared to historical study groups, including ES \#4 with chronic GvHD [1, 9, 21].

Compared to survival data from non-transplanted patients with similar risk profiles [21], the patients in this study fared better. Post-relapse survival for all patients was 13 months, for ES patients 33 months and for RMS patients 8 months. Without CR2, median time to death in the study population of Ferrari et al. was 6 months [21].

Therefore, we hypothesize that there is a benefit in overall survival for the subgroup of high-risk patients in comparison to standard of care therapy that includes HDC as well. This survival benefit appears even more obvious when the subgroup of HLA-mismatched patients, who received DLI, is considered separately (40 months of median overall survival after allo-SCT for haploidentical transplanted patients versus 10 months for HLA-matched transplanted patients). In accordance, the post-relapse survival for haploidentical transplanted patients is higher than for those having received an HLA-matched graft (median time to death: 23 months versus 3 months), possibly originating from a stronger alloreactivity of donor cells against tumor alloantigens in a HLA-mismatched versus HLA-identical setting.

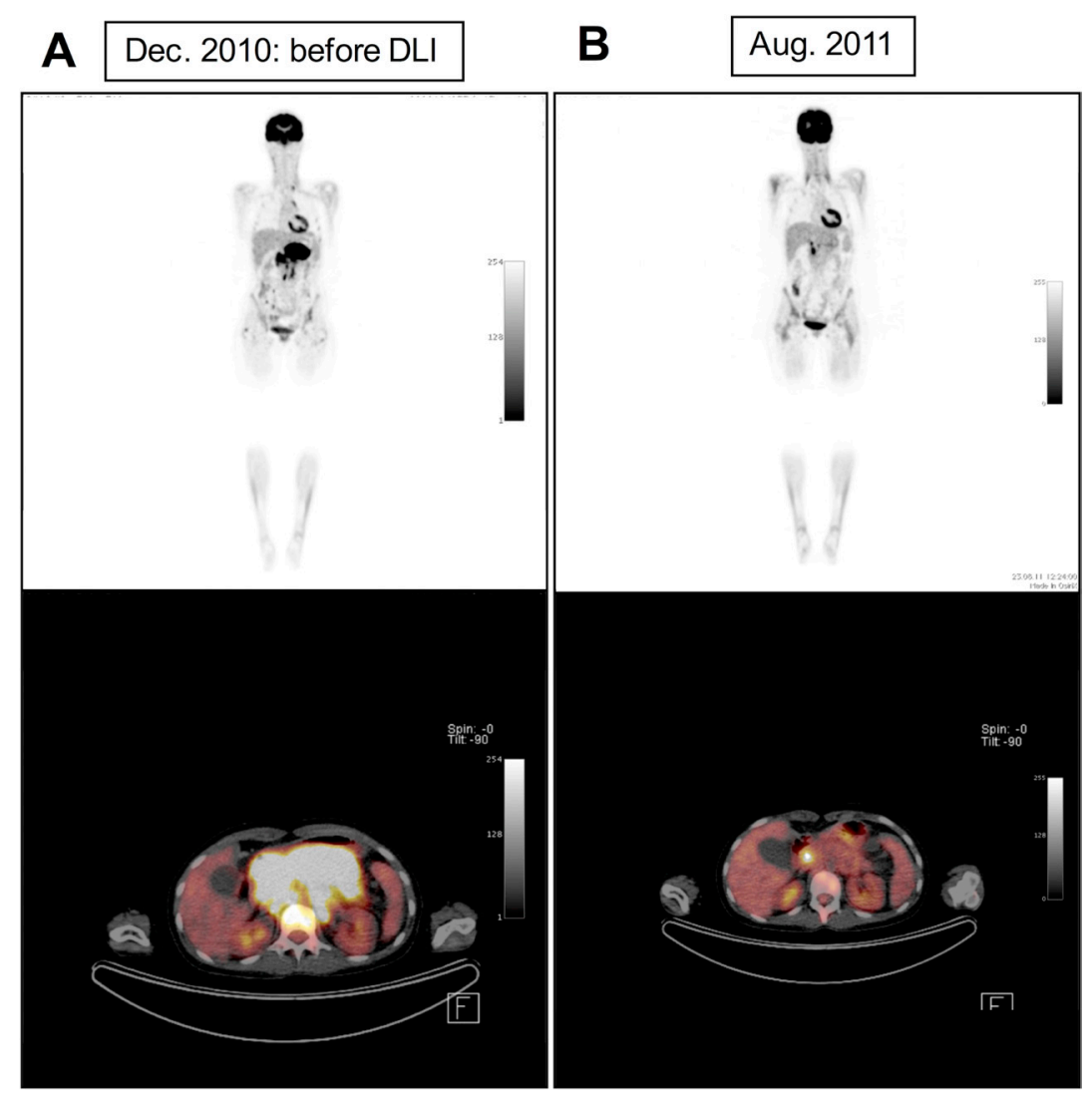

Figure 1: Positron emission tomography-computed tomography (PET-CT) of patient RMS\#4 shows reduction of pathological $\left[{ }^{18} \mathrm{~F}\right]$ fluorodeoxyglucose (FDG)-uptake of pancreatic tumour mass under combinatory treatment including DLI, hyperthermia and mini-ICE chemotherapy indicating partial tumor regression (A: before DLI, B: eight months after DLI). 
Table 2: Graft and DLI-related information

\begin{tabular}{|c|c|c|c|c|c|c|c|c|c|c|c|}
\hline 总 & 葛 & 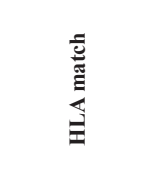 & 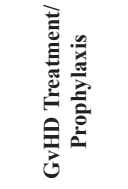 & 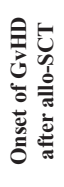 & 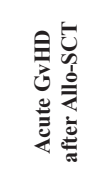 & 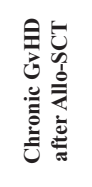 & 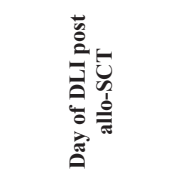 & 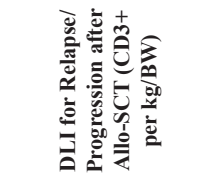 & 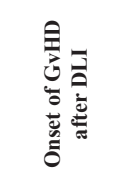 & 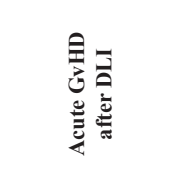 & 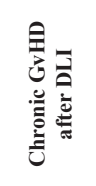 \\
\hline ES\#1 & $\begin{array}{l}\text { FLU/MEL/ } \\
\text { OKT3/TT }\end{array}$ & $\begin{array}{l}\text { haploidentical } \\
\text { (mother) }\end{array}$ & STER/CSA & $d+34$ & $\begin{array}{l}\text { Stage I-II } \\
\quad \text { (skin) }\end{array}$ & None & $\begin{array}{c}d+485, d+566 \\
d+639, d+691 \\
d+716\end{array}$ & $\begin{array}{l}\text { Six times; } 2.5,5,10 \text {, } \\
25,100 \text { and } 500 \times 10^{4}\end{array}$ & None & None & None \\
\hline $\mathrm{ES \# 2}$ & $\begin{array}{l}\text { FLU/MEL/ } \\
\text { OKT3/TT }\end{array}$ & $\begin{array}{l}\text { haploidentical; } \\
\text { class I matched } \\
\text { (father) }\end{array}$ & CSA & $d+63$ & $\begin{array}{l}\text { Stage I } \\
\text { (skin) }\end{array}$ & None & $\begin{array}{l}7 \text { times; in- } \\
\text { between } \mathrm{d}+642 \\
\text { and } \mathrm{d}+824\end{array}$ & $\begin{array}{c}\text { Seven times; } 2.5,5 \text {, } \\
10,25,100,500 \text { and } \\
1.000 \times 10^{4}\end{array}$ & None & None & None \\
\hline ES\#3 & $\begin{array}{l}\text { FLU/MEL/ } \\
\text { OKT3/TT }\end{array}$ & $\begin{array}{l}\text { HLA identical } \\
\text { match (sibling) }\end{array}$ & CSA & None & None & N.A. & $d+70, d+104$ & $\begin{array}{c}\text { Twice; } 10 \times 10^{4} \text { and } \\
100 \times 10^{4}\end{array}$ & None & None & None \\
\hline ES\#4 & $\begin{array}{l}\text { FLU/MEL/ } \\
\text { OKT3/TT }\end{array}$ & $\begin{array}{l}\text { haploidentical } \\
\text { (sibling) }\end{array}$ & $\begin{array}{l}\text { BASX, } \\
\text { ECP,STER/ } \\
\text { MMF, } \\
\text { OKT3 }\end{array}$ & None & None & None & $\begin{array}{l}\text { N.A. after } 1 \text { st four } \\
\text { DLIs; } 64 \text { times } \\
\text { in-between } d+606 \\
\text { and } d+917 \text {, and } \\
\text { six times } d+1081 \\
\text { and } d+1133\end{array}$ & $\begin{array}{l}74 \text { times; } 4 \text { times to } \\
\text { consolidate allo-SCT } \\
\text { up to } 30 \times 10^{4}, 64 \\
\text { times up to } 30 \times 10^{4} \\
\text { and six times up to } \\
\quad 200 \times 10^{4}\end{array}$ & $\begin{array}{c}\text { N.A. after } \\
1 \text { st } 4 \text { DLI, } \\
\text { d+63 after } \\
1 \text { st DLI/ } \\
\text { d+10 after } \\
\text { last six DLI }\end{array}$ & $\begin{array}{l}\text { twice; Stage II-III } \\
\text { (skin) after 1st } \\
\text { four DLIs; Stage } \\
\text { III-IV (intestine, } \\
\text { liver) after last six } \\
\text { DLIs up to } \\
200 \times 10^{4}\end{array}$ & Extended \\
\hline RMS\#1 & $\begin{array}{l}\mathrm{CRBPL} / \\
\mathrm{MEL} / \mathrm{TT}\end{array}$ & $\begin{array}{l}\text { HLA identical } \\
\text { match (sibling) }\end{array}$ & UK & None & None & None & N.A. & twice; $1.000 \times 10^{4}$ & None & None & N.A. \\
\hline RMS\#2 & $\begin{array}{l}\mathrm{BU} / \mathrm{CTX} / \\
\mathrm{TT}\end{array}$ & $\begin{array}{l}\text { HLA identical } \\
\text { match (sibling) }\end{array}$ & CSA & None & None & None & N.A. & $\begin{array}{c}\text { Seven times; } 10,30 \text {, } \\
50,100,250,500 \text { and } \\
1.000 \times 10^{4}\end{array}$ & None & None & None \\
\hline RMS\#3 & $\mathrm{CTX} / \mathrm{FLU}$ & $\begin{array}{l}\text { HLA identical } \\
\text { match (sibling) }\end{array}$ & Yes, but UK & N.A. & Stage III & Limited & N.A. & once; $10.000 \times 10^{4}$ & None & None & N.A. \\
\hline RMS\#4 & $\begin{array}{l}\text { FLU/MEL/ } \\
\text { OKT3/TT }\end{array}$ & $\begin{array}{l}\text { haploidentical } \\
\text { (father) }\end{array}$ & $\begin{array}{l}\text { ETN, MSC, } \\
\text { STER/ } \\
\text { MMF, } \\
\text { OKT3 }\end{array}$ & $\mathrm{d}+49$ & $\begin{array}{l}\text { Stage IV } \\
\text { (intestine) }\end{array}$ & Non & $d+576$ & once; $100 \times 10^{4}$ & $\begin{array}{l}\mathrm{d}+53 \text { (not } \\
\text { biopsy- } \\
\text { proven, but } \\
\text { responsive } \\
\text { to treatment) }\end{array}$ & Stage II-III (skin) & None \\
\hline
\end{tabular}

Abbreviations: allo-SCT = allogeneic stem cell transplantation; $\mathrm{BASX}=$ basiliximab; $\mathrm{BU}=$ busulfan; $\mathrm{BW}=$ body weight; $\mathrm{CSA}=$ cyclosporine $\mathrm{A} ; \mathrm{CTX}=$ cyclophosphamide; $\mathrm{CRBPL}=$ carboplatin; $\mathrm{d}$ = day; DLI = donor lymphocyte infusion; ECP = extracorporal photopheresis; ES = Ewing sarcoma; ETN = etanercept; FLU = fludarabin; GvHD = graft-versus-host disease; $\mathrm{HLA}=$ heuman leukocyte antigen; $\mathrm{MEL}=$ melphalan; $\mathrm{MMF}=$ mycophenolat mofetil; $\mathrm{MSC}=$ mesenchymal stem cells; $\mathrm{N} . \mathrm{A} .=$ not assessable; OKT3 = anti-CD3; RMS = rhabdomyosarcoma; $\mathrm{STER}=$ steroids; TT $=$ thiotepa; $\mathrm{UK}=$ unknown.

GvHD symptoms after DLI were absent in 6 out of 8 patients despite high doses of up to $1 \times 10^{8} \mathrm{CD}^{+} \mathrm{T}$ cells/ $\mathrm{kg}$. At the time of treatment, 4 DLI-non-responders had active tumor burden increasing in size, suggesting diseasetriggered immune-evasive mechanisms or even a general immune-suppressive host environment.

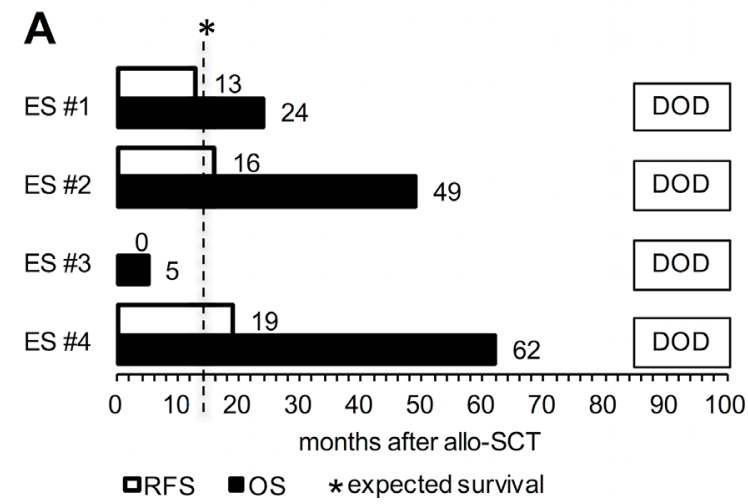

Eliciting a pro-inflammatory environment using allo-SCT may lead to enhanced phagocytic, NK cell as well as $\mathrm{T}$ cell activity [22]. In this regard, there is supporting evidence that alloreactive NK cells play a role in controlling minimal residual disease (MRD) in leukemia and solid pediatric tumors and are discussed to

Figure 2: Individual survival (in months) after allogeneic stem cell transplantation is depicted for ES (A) and RMS patients (B). Abbreviations: allo-SCT, allogeneic stem cell transplantation; CR, complete remission; DOD, death of disease; ES, Ewing's sarcoma patient; OS, overall survival; RFS, relapse-free survival; RMS, rhabdomyosarcoma patient. Patients ES \#1/\#2/\#4 and RMS \#4 received HLA-mismatched, haploidentical grafts. Patients ES \#3 and RMS \#1/\#2/\#3 received HLA-matched grafts from sibling donors. 
prolong survival after haploidentical allo-SCT compared to a HLA-matched setting [19]. A recent analysis showed even lower rates of chronic GvHD rates and similar survival outcomes of haploidentical allo-SCT compared to matched sibling or unrelated donor transplants by implementing post-transplantation cyclophosphamide [23].

In the present analysis, DLI after allo-SCT are a feasible therapy option for a subgroup of advanced ES and RMS patients. Of particular importance, GvHD rates and extent were controllable and no patient died of complications. Interpretation of the present data is limited due to low patient numbers and patient heterogeneity. Nevertheless, tumor control was observed in a number of patients.

Consecutively, our data suggest that high-risk pediatric ES and RMS patients when considered for an allo-SCT, should receive haploidentical grafts and additional pre-emptive DLI, in case acute GvHD symptoms are absent.

If the allo-SCT setting has the capacity to cause immune-susceptibility in bulky tumors, there is hope to cure allo-transplanted ES and RMS patients with high-risk relapse profiles in CR using pre-emptive DLI.

\section{MATERIALS AND METHODS}

\section{Data preparation and analysis}

We re-evaluated data of eight patients (14-26 years) from previous publications with advanced ES and RMS, who received DLI after allo-SCT between 1997 and 2011 [3, 9]. Median follow-up after allo-SCT was 27.5 months. Inclusion criteria were diagnosis of ES or RMS (all subtypes, respectively), DLI after allo-SCT and nonparticipation in ongoing prospective trials. Diagnosis and relapse were confirmed by histopathology. Tumor size was monitored with CT or MR-based imaging. Disease specific chromosomal translocations were detected by molecular-genetic testing. As we describe retrospective data of a small heterogeneous group we did not perform statistical significance tests.

\section{Definitions}

Disease was staged according to WHO classifications. Complete remission (CR) was defined as the absence of detectable disease, progressive disease (PD) as at least 25\% increase in tumor volume of previous lesions despite treatment. Partial remission (PR) was defined as at least 50\% tumor volume reduction. Residual disease included both $\mathrm{PD}$ and PR. Stable disease (SD) was defined as neither PD, PR nor CR. GvHD was graded using the Glucksberg criteria. The period of CR after allo-SCT until re-occurrence of any local or metastatic disease was termed relapse-free survival (RFS). Overall survival after allo-SCT (OS) was calculated from the time of allo-SCT until time of death. Post-relapse survival (PRS) was calculated from the time of most recent relapse after allo-SCT until death of disease (DOD). Expected median survival after allo-SCT is referred to most recent published data, i.e. 12 months for both ES [21] and RMS patients [9]. All patients and their legal guardians signed informed consent prior to treatment which was approved by the institutional review boards according to precepts established by the Helsinki Conference Declaration.

\section{Graft source, HLA-match and GvHD prophylaxis/treatment}

7 out of 8 patients received CD3/CD19-depleted allografts from peripheral blood (PB). Only RMS\#2 received a bone marrow $(\mathrm{BM})$ allograft. 4 out of 8 patients (ES\#3, RMS\#1, \#2 and \#3) received HLA-matched grafts from sibling-donors. Patients ES\#1, \#2, \#4 and RMS\#4 received HLA-mismatched grafts from family members (Table 2). Conditioning regimens, GvHD prophylaxis and treatment are also listed in Table 2. Patients did not receive immunosuppressive therapy during or after DLI. When patients developed GvHD symptoms ( $\left.{ }^{\circ} \mathrm{II}\right)$, DLI were discontinued and immunosuppression was started (compare Table 2).

Information on patients' pretreatment is elaborated in the Supplementary Materials.

\section{ACKNOWLEDGMENTS}

We would like to thank all patients and their families as well as treating physicians and nurses for their contribution to this study.

\section{CONFLICTS OF INTEREST}

S. Burdach has ownership interest in PDL biopharma and holds intellectual property (EU and US patents) in gene expression analysis. The other authors declare no potential conflicts of interest.

\section{FUNDING}

The study was supported by grants to SB from Wilhelm Sander-Stiftung (2006.109.1), ElseKröner-Fresenius-Stiftung (P31/08//A123/07) and the Deutsche Kinderkrebsstiftung (DKS 2010.07); SB and UT received grants from the Federal Ministry of Education and Research Germany (TranSarNet 01GM1104B; TranSarNet 01GM0869). IvL received a grant from Cura Placida Children's Cancer Research Foundation. 


\section{REFERENCES}

1. Thiel U, Wawer A, Wolf P, Badoglio M, Santucci A, Klingebiel T, Basu O, Borkhardt A, Laws HJ, Kodera Y, Yoshimi A, Peters C, Ladenstein R, et al. No improvement of survival with reduced- versus high-intensity conditioning for allogeneic stem cell transplants in Ewing tumor patients. Ann Oncol. 2011; 22:1614-21. https://doi.org/10.1093/ annonc/mdq703.

2. Burdach S, Meyer-Bahlburg A, Laws HJ, Haase R, van Kaik B, Metzner B, Wawer A, Finke R, Gobel U, Haerting J, Pape H, Gadner H, Dunst J, et al. High-dose therapy for patients with primary multifocal and early relapsed Ewing's tumors: results of two consecutive regimens assessing the role of total-body irradiation. J Clin Oncol. 2003; 21:30728. https://doi.org/10.1200/JCO.2003.12.039.

3. Thiel U, Wawer A, von Luettichau I, Bender HU, Blaeschke F, Grunewald TG, Steinborn M, Roper B, Bonig H, Klingebiel T, Bader P, Koscielniak E, Paulussen M, et al. Bone marrow involvement identifies a subgroup of advanced Ewing sarcoma patients with fatal outcome irrespective of therapy in contrast to curable patients with multiple bone metastases but unaffected marrow. Oncotarget. 2016; 7:70959-68. https://doi.org/10.18632/ oncotarget.10938.

4. Stevens MC. Treatment for childhood rhabdomyosarcoma: the cost of cure. Lancet Oncol. 2005; 6:77-84. https://doi. org/10.1016/S1470-2045(05)01733-X.

5. Koscielniak E, Gross-Wieltsch U, Treuner J, Winkler $\mathrm{P}$, Klingebiel $\mathrm{T}$, Lang $\mathrm{P}$, Bader $\mathrm{P}$, Niethammer $\mathrm{D}$, Handgretinger R. Graft-versus-Ewing sarcoma effect and long-term remission induced by haploidentical stemcell transplantation in a patient with relapse of metastatic disease. J Clin Oncol. 2005; 23:242-4. https://doi. org/10.1200/JCO.2005.05.940.

6. Ohta H, Hashii Y, Yoshida H, Kusuki S, Tokimasa S, Yoneda A, Fukuzawa M, Inoue N, Hara J, Kusafuka T, Ozono K. Allogeneic hematopoietic stem cell transplantation against recurrent rhabdomyosarcoma. J Pediatr Hematol Oncol. 2011; 33:e35-8. https://doi.org/10.1097/ MPH.0b013e3181e7ddc5.

7. Kolb HJ. Graft-versus-leukemia effects of transplantation and donor lymphocytes. Blood. 2008; 112:4371-83. https:// doi.org/10.1182/blood-2008-03-077974.

8. Lissat A, Joerschke M, Shinde DA, Braunschweig T, Meier A, Makowska A, Bortnick R, Henneke P, Herget G, Gorr TA, Kontny U. IL6 secreted by Ewing sarcoma tumor microenvironment confers anti-apoptotic and celldisseminating paracrine responses in Ewing sarcoma cells. BMC Cancer. 2015; 15:552. https://doi.org/10.1186/ s12885-015-1564-7.

9. Thiel U, Koscielniak E, Blaeschke F, Grunewald TG, Badoglio M, Diaz MA, Paillard C, Prete A, Ussowicz M, Lang P, Fagioli F, Lutz P, Ehninger G, et al. Allogeneic stem cell transplantation for patients with advanced rhabdomyosarcoma: a retrospective assessment. $\mathrm{Br} \mathrm{J}$ Cancer. 2013; 109:2523-32. https://doi.org/10.1038/ bjc.2013.630.

10. Baird K, Fry TJ, Steinberg SM, Bishop MR, Fowler DH, Delbrook CP, Humphrey JL, Rager A, Richards K, Wayne AS, Mackall CL. Reduced-intensity allogeneic stem cell transplantation in children and young adults with ultrahigh-risk pediatric sarcomas. Biol Blood Marrow Transplant. 2012; 18:698-707. https://doi.org/10.1016/j. bbmt.2011.08.020.

11. Thiel U, Schober SJ, Einspieler I, Kirschner A, Thiede M, Schirmer D, Gall K, Blaeschke F, Schmidt O, Jabar S, Ranft A, Alba Rubio R, Dirksen U, et al. Ewing sarcoma partial regression without GvHD by chondromodulin-I/HLAA*02:01-specific allorestricted $\mathrm{T}$ cell receptor transgenic $\mathrm{T}$ cells. Oncoimmunology. 2017; 6:e1312239. https://doi.org/ 10.1080/2162402X.2017.1312239.

12. Merchant MS, Wright M, Baird K, Wexler LH, RodriguezGalindo C, Bernstein D, Delbrook C, Lodish M, Bishop R, Wolchok JD, Streicher H, Mackall CL. Phase I Clinical Trial of Ipilimumab in Pediatric Patients with Advanced Solid Tumors. Clin Cancer Res. 2016; 22:1364-70. https:// doi.org/10.1158/1078-0432.CCR-15-0491.

13. Rizvi NA, Hellmann MD, Snyder A, Kvistborg P, Makarov V, Havel JJ, Lee W, Yuan J, Wong P, Ho TS, Miller ML, Rekhtman N, Moreira AL, et al. Cancer immunology. Mutational landscape determines sensitivity to PD-1 blockade in non-small cell lung cancer. Science. 2015; 348:124-8. https://doi.org/10.1126/science.aaa1348.

14. Berghuis D, de Hooge AS, Santos SJ, Horst D, Wiertz EJ, van Eggermond MC, van den Elsen PJ, Taminiau AH, Ottaviano L, Schaefer KL, Dirksen U, Hooijberg E, Mulder A, et al. Reduced human leukocyte antigen expression in advanced-stage Ewing sarcoma: implications for immune recognition. J Pathol. 2009; 218:222-31. https://doi. org/10.1002/path.2537.

15. Brinkrolf $P$, Landmeier S, Altvater B, Chen C, Pscherer S, Rosemann A, Ranft A, Dirksen U, Juergens H, Rossig C. A high proportion of bone marrow $\mathrm{T}$ cells with regulatory phenotype (CD4+CD25hiFoxP3+) in Ewing sarcoma patients is associated with metastatic disease. Int J Cancer. 2009; 125:879-86. https://doi.org/10.1002/ijc.24461.

16. Sorbye SW, Kilvaer T, Valkov A, Donnem T, Smeland E, Al-Shibli K, Bremnes RM, Busund LT. Prognostic impact of lymphocytes in soft tissue sarcomas. PLoS One. 2011; 6:e14611. https://doi.org/10.1371/journal.pone.0014611.

17. Joyce JA, Fearon DT. T cell exclusion, immune privilege, and the tumor microenvironment. Science. 2015; 348:7480. https://doi.org/10.1126/science.aaa6204.

18. Merchant MS, Bernstein D, Amoako M, Baird K, Fleisher TA, Morre M, Steinberg SM, Sabatino M, Stroncek DF, Venkatasan AM, Wood BJ, Wright M, Zhang H, et al. Adjuvant Immunotherapy to Improve Outcome in HighRisk Pediatric Sarcomas. Clin Cancer Res. 2016; 22:318291. https://doi.org/10.1158/1078-0432.CCR-15-2550. 
19. Schlegel P, Feuchtinger T, Nitschke-Gerard C, Seidel UJ, Lang AM, Kyzirakos C, Teltschik HM, Ebinger M, Schumm M, Koscielniak E, Handgretinger R, Lang P. Favorable NK cell activity after haploidentical hematopoietic stem cell transplantation in stage IV relapsed Ewing's sarcoma patients. Bone Marrow Transplant. 2015; 50:S72-6. https:// doi.org/10.1038/bmt.2015.100.

20. Lang P, Pfeiffer M, Muller I, Schumm M, Ebinger M, Koscielniak E, Feuchtinger T, Foll J, Martin D, Handgretinger R. Haploidentical stem cell transplantation in patients with pediatric solid tumors: preliminary results of a pilot study and analysis of graft versus tumor effects. Klin Padiatr. 2006; 218:321-6. https://doi. org/10.1055/s-2006-942256.

21. Ferrari S, Luksch R, Hall KS, Fagioli F, Prete A, Tamburini A, Tienghi A, DiGirolamo S, Paioli A, Abate ME, Podda M, Cammelli S, Eriksson M, et al. Post-relapse survival in patients with Ewing sarcoma. Pediatr Blood Cancer. 2015; 62:994-9. https://doi.org/10.1002/pbc.25388.

22. Bouchlaka MN, Redelman D, Murphy WJ. Immunotherapy following hematopoietic stem cell transplantation: potential for synergistic effects. Immunotherapy. 2010; 2:399-418. https://doi.org/10.2217/imt.10.20.

23. Martinez C, Gayoso J, Canals C, Finel H, Peggs K, Dominietto A, Castagna L, Afanasyev B, Robinson S, Blaise D, Corradini P, Itala-Remes M, Bermudez A, et al. Post-Transplantation Cyclophosphamide-Based Haploidentical Transplantation as Alternative to Matched Sibling or Unrelated Donor Transplantation for Hodgkin Lymphoma: A Registry Study of the Lymphoma Working Party of the European Society for Blood and Marrow Transplantation. J Clin Oncol. 2017; 35:3425-32. https:// doi.org/10.1200/JCO.2017.72.6869. 